\title{
WIESEAW WYDRA
}

\section{Pieśni nabożne... z krakowskiej oficyny Antoniego Wosińskiego (1627)}

W zbiorach Biblioteki Eskurialu koło Madrytu (Real Biblioteca de San Lorenzo de El Escorial, sygn. B. O-VIII.29) ${ }^{\mathrm{I}}$ znajduje się unikatowy egzemplarz drukowanego w 1627 roku w Krakowie kancjonału katolickiego (bez melodii). Nie odnotowuje go żadna bibliografia ${ }^{2}$, trudno jednak uznać ten druk za całkowicie nieznany. Krótko bowiem o nim pisze Paulina Buchwald-Pelcowa $\mathrm{w}$ artykule o polonikach $\mathrm{w}$ zbiorach hiszpańskich ${ }^{3}$, a w jednej ze swoich prac wspomina go Adolf Pawiński, wybitny historyk, który u schyłku XIX wieku odwiedził Eskurial ${ }^{4}$. Książkę tę można śmiało uznać za najstarszy w ogóle znany drukowany polski kancjonał katolicki. Pieśni postne starożytne ukazały się drukiem co prawda wcześniej (pierwsze znane wydanie: około 1607 roku - przed 1618 rokiem w oficynie Sebastiana Sternackiego w Rakowie, drugie: Kraków, Marcin Horteryn, 1617, trzecie: Wilno, Leon Mamonicz, po 1609, a przed 1627 ro-

${ }^{\text {I }}$ Reprint tego kancjonału został opublikowany w niewielkim nakładzie w serii Libri librorum, red. K. Meller i W. Wydra, Eximiorum Poloniae librorum bibliotheca, red. K. Meller, Poznań 2011, ss. 388. Fotografie tego bezcennego zabytku otrzymałem od pana Wojciecha Rębowskiego, za co składam mu najserdeczniejsze podziękowanie.

${ }^{2}$ Oto katalogowy opis tego unikatowego druku: Pieśni nabożne na śrwięta uroczyste wedlug porządku Kościoła Ś. Katolickiego na cały rok z wielka pilnościa zebrane. Przydane sa niektore Psalmy Dawidowe ku śpiewaniu ludziom zwyczajne. Kraków, u Antoniego Wosińskiego, 1627. 16º podł.; k. 176, sygn. A-Y ${ }^{8}$.

3 P. Buchwald-Pelcowa, Polonica XVI w wieku w bibliotekach biszpańskich, w: Z badań nad dawna ksiażka. Studia ofiarowane profesor Alodii Kazeckiej-Gryczowej w 85-lecie urodzin, Warszawa 1991, t. 1, s. 97-98.

4 A. Pawiński, Hiszpania. Listy zpodróży. Warszawa 1898, s. 379-380. 
kiem $)^{5}$, lecz trudno je uznać za kancjonał, gdyż zawierają tylko 21 pieśni. Natomiast duży już, prawdziwy kancjonał katolicki Stanisława Serafina Jagodyńskiego pt. Pieśni katolickie wydrukował Franciszek Cezary w Krakowie około 1638 roku, a więc w dziesięć lat po Pieśniach nabożnych, o których tu mowa. Pieśni nabożne to obszerny kancjonal, zawiera bowiem ponad 140 utworów, polskich i łacińskich (w tym kilkakrotnie polskie przekłady lub odpowiedniki tekstów łacińskich).

Pieśni nabożne odbił Antoni Wosiński w 1627 roku (na karcie tytułowej cyfra $2 \mathrm{w}$ dacie rocznej omyłkowo została odwrócona), typograf krakowski działający w latach 1617-1642 ${ }^{6}$. Ale edycja tego zbioru pieśni z pewnością nie była jego pomysłem. Przedrukował, najprawdopodobniej $\mathrm{z}$ niewielkimi zmianami, jakieś wcześniejsze wydanie tego kancjonału. Znamy bowiem ze skromnego opisu jeden takiż kancjonał tłoczony w 1621 roku, a nie można przecież wykluczyć, że drukowany był przedtem nie raz, może już od schyłku XVI wieku, lecz egzemplarze się nie zachowały, co potwierdzają późniejsze edycje, o których niżej†.

Efraim Oloff w swoim cennym dziele Polnische Liedergeschichte von polnischen Kirchen-Gesängen wśród dawnych kancjonałów polskich wymienia również taki, katolicki: „Sebastian Jastrzębski, hat ediret: Pieśni nabożne na uroczyste święta, w Krak. 1621. d. i. andächtige Lieder auf die hohen Fest-Tage. vid. Prawidło wiary Catholickiey, in Mst. p. 430. s. die Richtigkeit des Cathol. Glaubens" ${ }^{8}$. W innym miejscu ponownie pisze: „Pieśni nabożne na uroczyste Swięta, d. i. andächtige Gesänge auf die hohen Festtage / Seb. Jastrzębski, Cracov. 1621. vid. Prawidło Wiary Mst. Richtischnur des Glaubens" ". Oloff nie miał w ręku tej książki, opis zaczerpnął z bliżej nam dziś nieznanego

5 Por. m.in. W. Wydra, O nieznanej trzeciej edycji „Pieśni postnych starożytnych” i nieznanym kalendarzu Andrzeja Rymszy, „Slavia Occidentalis” 55 (1998), s. 139-144.

${ }^{6}$ Zob. o nim Drukarze dawnej Polski od XV do XVIII wieku, t. 1: Matopolska, część 2: Wiek XVII-XVIII, red. J. Pirożyński, Kraków 2000, vol. 2, s. 656-671.

7 Zwróćmy tu uwagę, że w 1620 roku w oficynie Cezarego w Krakowie ukazał się dość obszerny kancjonał katolicki w języku niemieckim (Katholische Gesang... , zob. M. Malicki, Repertuar wydawniczy drukarni Franciszka Cezarego starszego 1616-1651. Cz. I: Bibliografia druków, Kraków 2010, nr 57; unikatowy egzemplarz w Bibliotece Jagiellońskiej) i z całą pewnością przeznaczony był dla zamieszkujących Rzeczpospolitą (m.in. Kraków) niemieckich katolików. Trudno zatem sobie wyobrazić, aby wcześniej nie ukazywały się drukiem podobne publikacje w języku polskim.

${ }^{8}$ E. Oloff, Polnische Liedergeschichte von polnischen Kirchen-Gesängen, Dantzig 1744, s. 98.

9 Ibidem, s. 263. 
rękopisu, z którego korzystał, pisząc swoją rozprawę o dziejach polskiej pieśni: Prawidło wiary Catbolickiey ${ }^{\mathrm{IO}}$. Od niego tę informację przejęli różni potem bibliografowie, czyniąc często z wymienionego przez Oloffa Sebastiana Jastrzębskiego autora tego kancjonału ${ }^{I I}$. Jastrzębski jednak to nie Jagodyński i nie wydaje się prawdopodobne, aby ten kancjonał ułożył. Nie zauważano, że Oloff przytacza nazwisko nie autora, ale drukarza Pieśni nabożnych na uroczyste święta z 1621 roku, Sebastian Jastrzębski był bowiem właścicielem niewielkiej drukarni w Krakowie w latach 1618/1619-1629, a handlował przede wszystkim dewocjonaliami i trudnił się różnymi interesami. Do dziś zachował się tylko jeden jego druk ${ }^{\mathrm{I2}}$.

To, że istniało wcześniejsze wydanie Pieśni nabożnych na święta uroczyste, potwierdza zachowany inwentarz księgarni Andrzeja Cichończyka w Jarosławiu z 1621 roku. Znajdujemy w nim książkę: Pieśni nabożnych na święta uroczyste w kantyczkach, dziesięcioro białej oprawy. Tychże pieśni w pargaminie dwadzieścia $i$ sześcioro ${ }^{\mathrm{I}}$. Cichończyk utrzymywał kontakty handlowe z księgarzami i drukarzami krakowskimi. Zmarł krótko po 3 września 1621 roku, a inwentarz zasobu jego księgarni wpisano do księgi wójtowskiej miasta Jarosławia 16 października 1621 roku ${ }^{\mathrm{I}}$. Wymienione $\mathrm{w}$ inwentarzu „Pieśni nabożne na święta uroczyste w kantyczkach" to najprawdopodobniej egzemplarze z drukarni Jastrzębskiego, ale nie można wykluczyć (zważywszy na datę śmierci księgarza), że było to jakieś jeszcze wcześniejsze inne wydanie i z innej oficyny.

Pieśni nabożne na święta uroczyste wedlug porzadku Kościoła świętego katolickiego to $\mathrm{w}$ dziejach polskiej kultury niezwykła książka, gdyż pod tym samym lub nieznacznie zmienianym tytułem była wielokrotnie drukowana przez kilka wieków. Niestety, ani nie znamy, ani nie poznamy liczby wszystkich wydań, bo wiadomości o tym kancjonale zachowały się $\mathrm{w}$ nielicznych dawnych notach bibliograficznych, zaś egzemplarze są niezwy-

то $\mathrm{W}$ innym jeszcze miejscu Oloff też powołuje się na ów rękopis zmieniając jednak nieco tytuł: „vid. Wiary Katholickiey prawidło in Msto” (ibidem, s. 260).

II Por. Estreicher XVIII 512.

I2 O Jastrzębskim zob. Drukarze dawnej Polski, t. 1, s. 260-262. Por. też R. Żurkowa, Ksiegarstwo krakowskie w pierwszej połowie XVII wieku, Kraków 1992, s. 24, 66, 76, 95, 98, 169.

I3 A. Lewicka-Kamińska, Inwentarz księgarni Andrzeja Cichończyka w Jarostawiu z r. 1621. „Roczniki Biblioteczne” 5 (1961), s. 286 (nr 186). Lewicka-Kamińska tę pozycję w inwentarzu objaśnia: „Jastrzębski Sebastian, Pieśni nabożne na święta uroczyste. Kraków 1621 . E XVIII 512 powtarza za Jocherem” (przypis).

${ }_{4}$ Ibidem, s. 254-256. 
kle rzadkie - najczęściej ocalały tylko pojedyncze, unikatowe, nieraz zdefektowane egzemplarze niektórych edycji. Książeczka ta została zaczytana, a do jej zagubienia przyczynił się zapewne też niewielki format: podłużne $16^{\circ}$ (później też niekiedy $8^{\circ}$ ). Oto mocno niekompletny, doraźnie sporządzony wykaz wydań tego kancjonału po rok $1800^{15}$ :

1. Pieśni nabożne na uroczyste święta. Kraków, Sebastian Jastrzębski, 1621. Estr. XVIII 512, XXIV 264.

2. Pieśni nabożne na śweięta uroczyste wedhugporzadku Kościota Ś. Katolickiego na caby rok z wielka pilnościa zebrane. Przydane sa niektore Psalmy Dawidowe ku śpiewaniu ludziom zwyczajne. Kraków, Antoni Wosiński, 1627. 16 ${ }^{\circ}$ podł. Estr. nie not.

3. Pieśni nabożne na śzeięta uroczyste wedtugporzadku Kościota Ś. Katolickiego przez caby rok pilno zebrane. Przydane sa psalmy Dawida ś. $i$ insze różne pieśni do śpiewania zwyczajne. Kraków, [b. d.], 1643. 16 ${ }^{\circ}$ podł. Estr. XXIV 264-265 (unikatowy egzemplarz w Bibliotece Uniwersyteckiej we Wrocławiu).

4. Pieśni nabożne na śweięta uroczyste wedtug porzadku Kościota Ś. Katolickiego na cały rok pilnie zebrane. Przydane sa Psalmy Dawida $i$ insze nowe pieśni ludziom do śpiewania zwyczajne. Warszawa, w drukarni Piotra Elerta, [b. r., przed 1653]. 16 ${ }^{\circ}$ podł. Estr. nie not. ${ }^{\mathrm{I} 6}$

5. Pieśni nabożne na święta uroczyste wedtugporządku Kościoła Świętego Katolickiego rzymskiego na caby rok zebrane. Z przydatkiem wielu pieśni wydrukowane. Kraków, w Drukarni Michała Janiszewskiego, 1672. 12ํㅜ podł. Estr. XXIV 265 (według Estreichera egzemplarz miał się znajdować w Bibliotece Uniwersyteckiej w Warszawie $)^{\mathrm{I} 7}$.

6. Pieśni nabożne na święta uroczyste... Słuck, [Druk. Radziwiłłowska], 1674. 16º podł. Estr. XXIV 265 (egzemplarz był w Bibliotece Uniwersyteckiej w Helsinkach $)^{8}$.

I5 Niektóre z wymienionych niżej edycji tego kancjonału przywołuje P. Buchwald-Pelcowa w artykułach Pieśń Ockinij się, Lechu. Przemiany tekstu i jego rola w literaturze $i$ życiu spotecznym i Pieśni patriotyczne i pieśni religijne „po potopie. Zob. P. Buchwald-Pelcowa, Historia literatury $i$ historia ksiażki. Studia nad ksiażka i literatura od średniowiecza po wiek XVIII, Kraków 2006, s. 404-405, 425-426 i n. Autorka odnotowuje tam także kilka innych, nieznanych mi jego wydań.

I6 Składka pierwsza z kartą tytułową w posiadaniu piszącego te słowa.

${ }_{77}$ Opis ten podaję za Estreicherem, choć musi tu być niewątpliwie jakaś pomyłka co do drukarza. Krakowska drukarnia Michała Janiszewskiego jest zupełnie nieznana. Egzemplarza tej książki dziś nie ma w Bibliotece Uniwersyteckiej w Warszawie.

I8 Inwentarz oficyny w Słucku z 1687 roku wymienia tę książkę jako Kantyczki i według niego nakład wynosił 3270 egzemplarzy. Zob. Drukarze dawnej 
7. Pieśni nabożnena śweięta uroczyste. Kraków1681. 16ํํ․ Estr. XXIV 265 (egzemplarz nieznany, zob. E. Oloff, op.cit., s. 266).

8. Pieśni nabożne na święta uroczyste wedlug porzadku Kościoła Ś. Katolickiego, a teraz z przydatkiem wielu rotut $i$ nowych pieśni wydrukowane. Poznań, w Drukarni Akademickiej, 1697. $16^{\circ}$ podł. Estr. nie not. (unikatowy egzemplarz znajduje się w Bibliotece OO. Franciszkanów Poznaniu).

9. Pieśni nabożne wedtug obrzędu Kościoła Ś. Katolickiego, sama prostota przyjemne, dla ś. nabożeństwa powabne [...]. Z przydatkiem wielu nowych ś. Pańskich świeżo wydane. Kalisz, w dru-

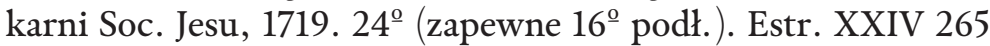
(egzemplarz nieznany).

10. Pieśni nabożne na święta uroczyste wedhug porzadku Kościoła Ś. Katolickiego na caly rok zebrane, a teraz z przydatkiem wielu rotut i nowych pieśni wydrukowane. Kraków 1720. 24ํㅡ (zapewne $16^{\circ}$ podł.). Estr. XXIV 265 (egzemplarz nieznany, zob. E. Oloff, op.cit., s. 268).

11. Kancjonat pieśni nabozinych, wedhug obrzędów Kościoła Śreiętego Katolickiego na uroczystości całego roku. Z przydatkiem wielu nowych sporzadzony i wydany. Kraków, w Drukarni Jakuba Matyaszkiewicza, 1721. 16 ${ }^{\circ}$ podł. (zob. E. Oloff, op.cit., s. 266 oraz K. Mrowiec, Zaginiony kancjonat Pieśni nabożnych z 1721 r. odkryty. „Roczniki Teologiczno-Kanoniczne” 24 (1977), z. 4, s. 169-183). Estr. nie not. (unikatowy egzemplarz w University Library Yale).

12. Kancjonat pieśni nabożnych wedtug obrzędów Kościota Ś. Katolickiego... Kraków, Jakub Matyjaszkiewicz, 1733. 16ํㅜㅇ podł. Estr. nie not. (egzemplarz w Bibliotece SS. Klarysek w Starym Sączu, sygn. 202).

13. Kancjonat pieśni nabożnych wedhug obrzędow Kościoła Śrwiętego Katolickiego na uroczystości catego roku. Z przydatkiem wielu nowych sporzadzony i wydany. Wratislaviae, w Druk. Akad. Colleg. Soc. Jesu, 1734. $8^{\circ}$. Estr. XIX 97 (egzemplarz w Bibliotece Kórnickiej).

14. Kancjonat pieśni nabożnych wedtug obrzędow Kościoła Śreiętego Katolickiego na uroczystości catego roku. Z przydatkiem wielu nowych y wybornych pieśni, nowo przedrukowany. Lublin, w Drukarni Coll. Soc. Jesu, 1745. $16^{\circ}$ podł. Estr. nie not. (egzemplarz w Bibliotece Akademii Nauk w Petersburgu, zob. О. Гусева, Собрание польских старопечатных книг в славянском фонде

Polski od XV do XVIII wieku, z. 5: Wielkie Ksiestwo Litewskie, oprac. A. Kawecka-Gryczowa, K. Korotajowa i W. Krajewski, Wrocław 1959, s. 232-233. Jedyny znany mi egzemplarz tej edycji znajdował się w Bibliotece Uniwersyteckiej w Helsinkach, lecz zaginą (informacja z 1997 roku). 
БАН. Несвижская ординатская библиотека Радзивиллов. Вып. 2, Санкт-Петербург, 2005, poz. 155).

15. Pieśni nabożne na święta uroczyste wedhug porzadku Kościoła Świętego Katolickiego Rzymskiego na caty rok zebrane. Na wielu miejscach poprawione $i$ z przydatkiem nowych pieśni przedrukowane. Wilno 1745. 16 ${ }^{\circ}$ podł. Estr. XXIV 265 (egzemplarz w Muzeum Narodowym w Krakowie, Zbiory Czapskich, sygn. 5683 ).

16. Pieśni nabożne na święta uroczyste... Wilno $1750.16^{\circ}$. Estr. XXIV 265 (egzemplarz nieznany).

17. Pieśni katolickie wedtug obrzędów Kościoła Ś. Rzymskiego na uroczystości calego roku. $Z$ przydatkiem nabożnych wielu nowych o różnych świętych pańskich świeżo wydane. Kraków, w Drukarni Akademickiej, 1754. 16º podł. Estr. XXIV 264 (egzemplarze w Bibliotece Jagiellońskiej i w Bibliotece Ossolińskich we Wrocławiu).

18. Pieśni nabożne wedtug porządku dorocznego świąt uroczystych Kościoła Ś. Katolickiego Rzymskiego zebrane i po kilka razy na świat wydane. Teraz jednak z opuszczeniem niektórych, mianowicie psalmów w mniej pospolitym używaniu będacych, a na to miejsce z przydatkiem nowych pieśni przedrukowane. Wilno, w Druk. J. K. M. Akad. Soc. Jesu, 1761. 16º podł. Estr. nie not. (egzemplarz w Bibliotece Narodowej w Wilnie).

19. Kancjonat pieśni nabożnych wedtug obrzędów Kościota Świętego Katolickiego na uroczystości całego roku. Z przydatkiem wielu nowych sporzadzony $i$ wydany. Wratislaviae, Druk. Akad. Colleg. Soc. Jesu, 1769. 8ํ․ Estr. XIX 97 (egzemplarze w Bibliotece Jagiellońskiej i w Bibliotece Narodowej w Warszawie).

20. Pieśni nabożne na święta uroczyste wedtug porzadku Kościoła Ś. Kațolickiego Rzymskiego na caty rok zebrane. I za pozwoleniem zwierzchności z przydaniem nowych pieśni przedrukowane.

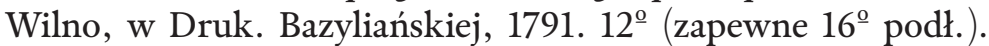
Estr. nie not. (egzemplarz w Bibliotece Narodowej w Wilnie).

21. Kancjonat albo pieśni nabożne wedlug obrządków Kościoła Ś. Katolickiego na uroczystości całego roku. Z przydatkiem wielu nowych o różyych świętych Pańskich nowo wydane. Kraków, w Druk. Anny Dziedzickiej i Sukcess., 1794. 16º podł. Estr. XIX 86 (egzemplarz w Bibliotece Ossolińskich we Wrocławiu).

22. Pieśni nabożne na święta uroczyste wedtug porzadku K@ścioła Ś. Katolickiego pilnie zebrane. Brzeg, J. Tramp, 1794. $12^{0}$. Estr. XXIV 265.

23. Pieśni nabożne wedtug obrząlków Kościoła Ś. Katolickiego sama prostota przyjemne. Dla szczerego nabożeństwa powabne. Na uroczystość całego roku z przydatkiem wielu różych Świę- 
tych Pańskich nowo wydane. Królewiec, drukowano u Daniela Krystofa Kantera, 1796. 16 ${ }^{\circ}$ podł. Estr. XXIV 265 (egzemplarz w Bibliotece PAN w Gdańsku i w Bibliotece Uniwersyteckiej w Warszawie, zob. Z. Rondomańska, Królewieckie druki polskich śpiewników religijnych Kantera z XVIII wieku. „Studia Warmińskie" 35 (I998), s. 173-183).

24. Pieśni nabożne na święta uroczyste wedhug porzadku Keścioła Ś. Katolickiego Rzymskiego, na caby rok zebrane... Wilno, w Druk. Bazyliańskiej, 1799. 16 ${ }^{\circ}$ podł. Estr. nie not. (egzemplarz m.in. w Bibliotece Akademii Nauk w Petersburgu).

25. Kancjonat albo pieśni nabożne wedhug obrzadków Kościoła Ś. Katolickiego na uroczystości całego roku. Z przydatkiem wielu nowych o różnych świętych Pańskich nowo wydane. Kraków, w Dukarni Akademickiej, 1800. 16º podł. Estr. nie not. (egzemplarz w Bibliotece Kórnickiej).

Pieśni nabożne na święta uroczyste to najczęściej $\mathrm{w}$ dziejach polskiego drukarstwa wydawana książka. Drukowana była w całej Rzeczypospolitej w różnych oficynach, i to nie tylko katolickich - w Krakowie, w Warszawie, w Słucku, w Wilnie, w Lublinie, w Kaliszu - i poza jej granicami - w Królewcu, we Wrocławiu, w Brzegu. Karol Mrowiec, opisując odnaleziony Kancjonat pieśni nabożnych z 1721 roku, zastanawia się, gdzie szukać jego pierwowzoru i „w jakim stosunku pozostaje on do współczesnych mu druków, jaki wywarł wpływ na kancjonały $\mathrm{z}$ lat późniejszych" ${ }^{\text {I9 }}$. Otóż pierwowzoru należy szukać w edycji z 1621 roku (lub, jak należy sądzić, jeszcze wcześniejszej, lecz niedochowanej). Wzorem zaś dla każdej następnej była z kolei poprzednia edycja (czy poprzednie edycje). Zmieniała się jednak część tytułu (informowano w nim o zmianach i uzupełnieniach w „przydatkach”, a od XVIII wieku przed dawny tytuł Pieśni nabożne dodawano często słowo Kancjonat) i zmieniał się zasób utworów zależnie od czasu druku i miejsca druku, ale schemat kancjonału pozostawał zawsze ten sam (układ według roku liturgicznego z dodaniem różnych psalmów lub ich pominięciem oraz dodatku, często bardzo obszernego, z powszechnie śpiewanymi innymi utworami). Nowsze pieśni, coraz bardziej popularne, wypierały pieśni dawniejsze (choć zasób podstawowy długo się utrzymywał). Zwłaszcza dotyczyło to kolęd, które, traktowane przez Kościół z najwyższą nieufnością, wdzierały się obficie do naszego śpiewnika, zajmując w nim od schyłku XVII wieku coraz więcej miejsca. Przez to Pieśni nabożne na święta uroczyste są

I9 K. Mrowiec, op.cit., s. 182. 
bezcennym źródłem do poznania dziejów polskiej pieśni katolickiej, śledzenia chronologii, wariantów tekstowych i popularności w różnym czasie różnych utworów, ich zasięgu i regionalnego występowania, od Wilna po Kraków. I to nie tylko w wiekach XVII-XVIII, ale również $\mathrm{w} \mathrm{XIX}^{2 \circ}$, a nawet $\mathrm{w} \mathrm{XX}$ wieku, bo ostatnia ich edycja ukazała się w Suwałkach w 1995 roku $^{21}$. Pieśni nabożne, sprzedawane przede wszystkim pomiędzy dewocjonaliami na odpustach i jarmarkach, cieszyły zapewne ogromnym wzięciem i z nich dowiadujemy się, jak wyglądał i zmieniał się najbardziej popularny repertuar polskich pieśni katolickich w ciągu trzystu lat.

Stanowiąc tak nieocenione źródło, kancjonały te nie zostały dotąd należycie wykorzystane przez badaczy ${ }^{22}$. Nie wdając się tu w szczegółową analizę ich zawartości, zaznaczmy, że znajdują się w nich m.in. przekazy pieśni o średniowiecznym rodowodzie, które umożliwiają rozpoznać warianty, zrekonstruować często fragmentaryczne najdawniejsze przekazy i określić popularność oraz zasięg poszczególnych tekstów; pozwalają też dowiedzieć

2o Dla przykładu wymieńmy kilka wydań z XIX wieku (odsyłając do innych opisanych w Bibliografii Polskiej XIX stulecia Estreichera i jej drugiego, nowego wydania; zob. hasła Kancjonat i Pieśni, nie są one jednak kompletne):

Kancjonat pieśni nabożnych wedhug obrządku Kościoła Ś. Katolickiego na uroczystości całego roku z przydatkiem wielu nowych, o rózinych Ś. Ś. Pańskich z pozwoleniem starszych wydrukowany. W Drukarni Jasney Góry Częstochowskiej, 1802. $16^{\circ}$ podł. Estr. II 347.

Kancjonat albo Pieśni nabożne wedhug obrzadków Kościoła Ś. Katolickiego na uroczystości catego roku z przydatkiem wielu nowych o różnych ŚŚ. Pańskich. Nowo wydane. Kraków, druk Akadem., 1805. 16‥ Estr. II 347.

Kancjonat pieśni nabożnych wedhug obrzadku Kościoła Ś. Katolickiego na uroczystości całego roku z przydatkami nowych pieśni, osobliwie o Bożem Narodzeniu. Za dozwoleniem zwierzchności. Przemyśl, w drukarni Jana Gołębiowskiego, 1811. $16^{\circ}$ podł. Estr. II 349.

Pieśni nabożne na święta uroczyste wedlug porzadlku kościoła Ś. Rzymsko-Katolickiego na caby rok zebrane $i$ za pozwoleniem zwierzchności z przydaniem nowych pieśni przedrukowane.Wilno, Druk. XX. Bazylianów, 1822 (egzemplarz w Bibliotece Narodowej w Wilnie). Estr. III 394.

Kancjonal pieśni nabożnych wedhug obrządku Kościoła Kațolickiego na uroczystości całego roku z przydatkiem nowych pieśni osobliwie o Bożem Narodzeniu. Jasna Góra 1844 (egzemplarz w Woj. Bibl. Publicznej w Lublinie).

Kancjonal pieśni nabożnych wedlug obrządku kościoła Św. Katolickiego na uroczystości całego roku z przydatkiem wielu pieśni nabożnych o świętych pańskich. Warszawa, nakł. Lange, 1874 (Wilno, BN sygn. 1.65761).

2I Pieśni nabożne, wyd. J. Murawski, Suwałki 1995. Teksty pochodzą z: Pieśni nabożne na święta uroczyste podług porzadlku kościoła świętego rzymskokatolickiego na caly rok zebrane, Suwałki 1925.

${ }_{22}$ Do kancjonałów tych sięgnęły przede wszystkim dwie autorki: A. Nowicka-Jeżowa w pracy Pieśni czasu śmierci. Studium z historii duchowości XVI XVIII wieku (Lublin 1992) oraz P. Buchwald-Pelcowa w artykułach Pieśń Ocknij się, Lechu. Przemiany tekstu i jego rola w literaturze i życiu społecznym (op.cit.) i Pieśni patriotyczne i pieśni religijne „po potopie (op.cit.). 
się, co ze średniowiecznego dorobku w tej dziedzinie było znane w następnych wiekach ${ }^{23}$. Dotąd właściwie tylko Mikołaj Bobowski wykorzystał jeden z tych kancjonałów (drukowany w Krakowie w 1643 roku) w swojej edycji pieśni polskich z średniowiecza i wieku XVI ${ }^{24}$.

Ale Pieśni nabożne na śrwięta uroczyste są niezwykle cenne, jak już wspomniano, jeszcze bardziej dla badań nad tekstami katolickich pieśni religijnych od XVII wieku aż po II połowę XIX wieku. I znowu, nie wdając się w niemożliwą tu drobiazgową analizę, zwróćmy tylko uwagę, że jako pierwsza pieśń w tych kancjonałach występuje Rejowski Hejnat (w edycji z 1627 roku i następnych) o incipicie Hejnat wszyscy zaśpiewajmy. Nie zna tych przekazów Irena Rostkowska w Bibliografii dziet Mikołaja Reja ${ }^{25}$, odnotowuje tylko obecność tej pieśni w kancjonałach protestanckich. Przekazy Hejnału w Pieśniach nabożnych mocno się jednak różnią od jego pierwowzoru. Zachowują autorski akrostych Reja, choć jego wydawca pewnie nie miał świadomości, czyim dziełem jest ta pieśń, bo w układzie akrostychu są usterki. Nadto z Hejnałem połączona została inna pieśń, rozpoczynająca się od słów Panie Boże z wysokości, licząca siedem zwrotek ${ }^{26}$. Czesław Hernas w swojej monografii ${ }^{27}$ właściwie nie korzysta $\mathrm{z}$ tego przekazu ${ }^{28}$ i tym samym nie odnotowuje zupełnie obecności Rejowego Hejnału w kancjonałach katolickich. W dodatku nie zauważył, że złączona z Hejnałem pieśń Panie Boże z wysokości występuje w kancjonale Jagodyńskiego jako pierwsza wśród pieśni adwentowych. Pieśni nabożne na święta uroczysteświadczą też, że nie Jagodyński „pierwszy raz wprowadził [...] określenie »hejnał « przy pieśniach adwentowych”, jak sądzi Hernas ${ }^{29}$, lecz było to nawiązanie do wcześniejszej tradycji.

Znajdują się też w Pieśniach nabożnych liczne psalmy Jana Kochanowskiego. Janusz Pelc w swojej pracy poświęconej obecności utworów Kochanowskiego w kancjonałach stwierdził, że

${ }_{23}$ Np. tekst Bogurodzicy z kancjonału z 1734 i 1794 roku wydał Jerzy Woronczak (Bogurodzica, oprac. J. Woronczak, Wrocław 1962, s. 220-221, 233-234, Biblioteka Pisarzów Polskich, seria A nr 1; zob. też W. Wydra, Do dziejów Bogurodzicy, „Slavia Occidentalis” 43 (1986), s. 201-208).

${ }_{24}$ M. Bobowski, Polskie pieśni katolickie od najdawniejszych czasów do końca XVI wieku, „Rozprawy AU, Wydz. Filologiczny” 19 (1893), passim.

${ }_{25}$ Okres staropolski, Wrocław 1970.

${ }_{26}$ Przekaz ten wydał M. Bobowski, op.cit., s. 372-374. Bobowski korzystał z Pieśni nabożnych na śweięta uroczyste wydanych w Krakowie w 1643 roku.

${ }_{27} \mathrm{Cz}$. Hernas, Hejnaly polskie. Studium z bistorii poezji melicznej, Wrocław 1961, s. 43-56, 201.

${ }_{28}$ Zlekceważył wydanie Bobowskiego, pisząc, że jest „to przedruk całkowicie bez wartości” (s. 202).

29 Ibidem, s. 72. 
„w śpiewnikach katolickich z tych lat [XVII wiek - uzup. W.W.] teksty Kochanowskiego nie cieszą się tak wielkim powodzeniem. Wiązało się to zresztą nie tyle $\mathrm{z}$ brakiem zainteresowania odpowiednich kół, co z odmiennym charakterem nabożeństwa" ${ }^{\circ}$. Myli się on jednak bardzo, bo w Pieśniach nabożnych znajdziemy i liczne psalmy Kochanowskiego (ich wyliczenie zob. niżej), i jego pieśń Czego chceszpo (tak zam. od) nas, Panie, za twe bojne dary.

Rozpoczęty u schyłku XV wieku rozwój popularnej pieśni katolickiej w języku polskim w okresie reformacji został przytłumiony i twórczość katolicka w tej dziedzinie nie dorównywała protestanckiej ani liczebnością, ani jakością. Kościół wobec pieśni religijnej zajmował niezbyt przychylne stanowisko, bardziej ją tolerował, niż propagował. Po soborze trydenckim ustępstwo czyniono właściwie tylko dla tych utworów, które były „catholicae et antiquae, et ab ecclesia approbatae" ${ }^{3}$. Nowy rozwój polskiej pieśni $\mathrm{w}$ kościele katolickim nastąpił dopiero $\mathrm{w}$ okresie kontrreformacji, u schyłku XVI wieku Kościół w końcu jednak zaczął konkurować z protestantami w tej ważnej dla ludu formie udziału w życiu religijnym. W wydawaniu i upowszechnianiu wśród wiernych pieśni religijnych protestanci wszakże długo górowali nad kościołem katolickim. W ciągu XVI i XVII wieku ukazywały się drukiem liczne protestanckie kancjonały, m.in. Jana Seklucjana $(1547,1550,1559)$, Walentego z Brzozowa $(1554,1569)$, Piotra Artomiusza $(1578,1587,1595,1601$, 1620, 1640, 1646), Bartłomieja Groickiego (1559), Jana Zaremby (1558), a także licznie odbijane w Krakowie od lat trzydziestych XVI wieku pojedyncze pieśni. W XVI wieku nie ukazał się drukiem (a przynajmniej nie zachował się) żaden kancjonał katolicki. Pierwszym takim zbiorem są dopiero Pieśni postne starożytne, Pieśni katolickie nowo reformowane Jagodyńskiego oraz przede wszystkim Pieśni nabożne na święta uroczyste, o których tu mowa. Właśnie liczne edycje Pieśni nabożnych na śreięta uroczyste zmieniają ten skromny obraz, bo - jak się okazuje - liczba wydawanych kancjonałów katolickich była znacznie większa niż dotąd przypuszczano i starały się one jednak współzawodniczyć z podobnymi wydawnictwami protestanckimi.

30 Teksty Jana Kochanowskiego w kancjonałach staropolskich XVI $i$ XVII wie$k u$. „Odrodzenie i Reformacja w Polsce” 8 (1963), s. 237.

${ }^{\text {I }}$ Tak np. stanowi sobór diecezji warmińskiej w 1565 roku; cyt. za M. Bobowski, op.cit., s. 17. 


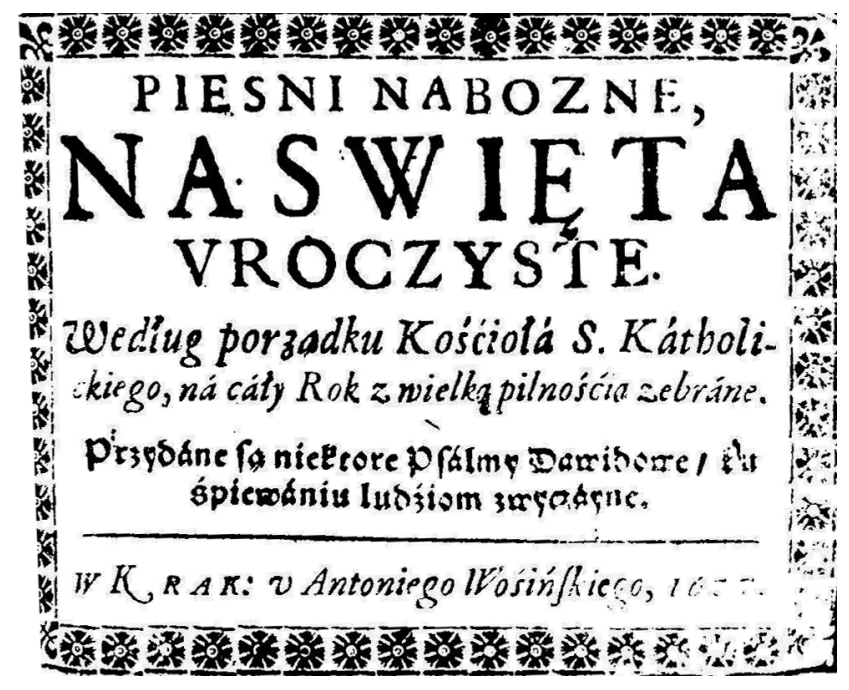

Wykaz utworów znajdujących w Pieśniach nabożnych na śrwięta uroczyste, drukowanych przez Antoniego Wosińskiego w 1627 roku, przedstawia się następująco:

Poczynają sie pieśni adwentowe nabożne

1. Hejnat wszyscy zaśpiewajmy, k. 2-3v

2. Mittit ad Virginem / Zdrowa bąź Maryja, Niebieska lili$j a$ (naprzemiennie zwrotki $\mathrm{w}$ języku łacińskim i polskim), k. $3 \mathrm{v}-5 \mathrm{v}$

3. Zdrowaś, od anjoła pozdrowienie miała, k. $5 \mathrm{v}-6$

4. O najaśniejsza lilija, Dziewico Panno Maryja, k. 6-7

5. Po upadku cztowieka grzesznego, k. 7-8v

6. Gwiazdo morza gtębokiego, k. 8v-9v

7. Archanjot boży Gabryjel postan do Panny Maryjej, k. 9v-11

8. Cesarzowno, krolewno niebieska, Wielka świattości anjelska, k. $11-12$

9. Bąź wesoła, Panno czysta, k. 12-13

10. Z wielmożności rady Trojce Świętej, k. 13-13v

11. Archanjot Gabryjel z nieba wysokiego, k. 14-15v

12. Urzad zbawienia ludzkiego, $\mathrm{k} .15 \mathrm{v}-16 \mathrm{v}$

13. O nadroższy kwiateczku, Panno panieńskiej czystości, k. 16v$17 \mathrm{v}$ 
14. Pieśń o korunce Panny Maryjej: Kto chce Pannie Maryjej stu$\dot{z y c}, \mathrm{k} .17 \mathrm{v}-21 \mathrm{v}$

15. Pieśń Rożanego wianka P. Maryjej: Z pomoca Boga miłego, k. $21 \mathrm{v}-23 \mathrm{v}$

16. Chwalmy Boga weszechmocnego, k. 23v-26

17. Ave stella matutina, k. 26

18. Zawitaj rana jutrzenko, k. $26 \mathrm{v}$

19. Imperatrix virgo gloriosa, $\mathrm{k} .26 \mathrm{v}-27$

20. Cesarzowno, krolewno niebieska, Laski bożej jesteś petna, k. $27-27 \mathrm{v}$

21. Ave, maris stella, k. $27 \mathrm{v}-28$

22. Zdrowas', grwiazdo morska, k. $27 \mathrm{v}-28$

23. Sanctissima Mater Dei, O Maria, flos virginum, k. $28 \mathrm{v}-29$

24. O naśziętsza i naczystsza Matko Boża, k. 29

Poczynają sie pieśni o Narodzeniu Pańskim

25. Nużeśmy chrześcijani, k. 29v-31

28. Kiedy krol Herod krolowat, k. 31-33 (błędnie 34)

29. Puer natus in Betleem / Dzieciątko sie narodziło (równolegle zwrotki w języku łacińskim i polskim), k. 33-33v

30. Puer nobis nascitur de pura Virgine, k. 34

31. Dzieciatko sie narodziło z czystej Dziewice, k. 34-34v

32. Colaudemus Christum Regem, k. 34v

33. Juвpochwalmy Krola tego, k. 34v-35

34. In natali Domini gaudent omnes angeli, k. 35

35. Na Boże narodzenie wesela sie anjeli, $\mathrm{k} .35-35 \mathrm{v}$

36. W dzień Bożego narodzenia weseli ludzie, k. 36-36v

37. Praeceteris na świecie laudemus Betbleem, k. 37-38

38. Mamy przyjaciela, Chrysta zbawiciela, k. 38-39

39. Angelus pastoribus dixit vigilantibus, k. 39-39v

40. Anjotpasterzom mowit, k. 39v-40 (błędnie 30)

Poczynają się pieśni o męce Pańskiej

41. Ojcze, Boże wszechmogacy, k. 40v-45

42. Wspominajac Boże stowa, k. 45-48v

43. Krzyżu święty nade wszytko, $\mathrm{k} .48 \mathrm{v}-51$

44. Płaczy dzisia duszo wszelka, k. 51-53

45. Patris sapientia, veritas divina, k. 53-53v

46. Madrość i prawda wieczna Ojca wszechmocnego, k. 53v-55

47. O duszo weszelka nabożna, k. 55-56

48. Daj nam Chryste wospomożenie, k. 56-57v

49. Choragiew Krola wiecznego, k. 57-58 
50. Procesyja na Kwietną Niedzielę, incipit: Cum appropinquaret Dominus Ierosolimam... (z śpiewami polskimi), k. 58v-63

51. <Ciemne jutrznie >, k. 63v-66v

Poczynają się pieśni o zmartwychwstaniu Pańskim

52. Przez twe śrwiete zmartwychrestanie, k. 66v

53. Wesoby nam dzień nastat, Gdy Pan Chrystus zreyciężyt, k. $66 \mathrm{v}-67$

54. Victime paschali laudes / Chrystus zmartwychwestat jest (naprzemiennie zwotki w języku łacińskim i polskim), k. 67$68 \mathrm{v}$

55. Surrexit Christus hodie, k. 68-69

56. Wstat Pan Chrystus z martwych ninie, k. 69-69v

57. Chrystus P. zmartwychrestat, k. 69-70

58. Surrexit Dominus valete luctus, k. 70-70v

59. Dnia tego śrwiętego wielkanocnego, $\mathrm{k} .70 \mathrm{v}$

60. Wesoby nam jest dzień nastat, Ktorego z nas każdy pożąat, k. $71-72$

Poczynają się pieśni o Duchu Świętym

61. Ducbu Święty, raczprzyść k nam, k. 72v-73v

62. Spiritus Sancti gratia, k. $73 \mathrm{v}-74$

63. Pan Chrystus dnia śweiatecznego, k. $74-74 \mathrm{v}$

64. Prośmyż dziś Śziętego Ducha, k. 74v-75

Poczynają się pieśni na Boże Ciało

65. Twoja cześć, chwata, nasz wieczny Panie, k. 75-76

66. Do ciebie Panie pokornie wolamy, k. 76-76v

67. Ave verum Corpus natum, k. $76 \mathrm{v}-77$

68. Witaj Ciało przenaśtwiętsze, k. 77

69. Każde stworzenie śpiewaj a dziśsawołaj, k. 77-78

70. Jesu, dulcis memoria, k. 78-78v

71. Jezu, wdzięczne pamiętanie, k. 78-79v

Poczynają się pieśni i psalmy Dawidowe ${ }^{32}$

72. Szcześliwey, ktory nie byt między ztemi w radzie (Ps 1$), \mathrm{k} .79 \mathrm{v}-$ $80 \mathrm{v}$

${ }^{32} \mathrm{Z}$ wyjątkiem tekstów nr 82 (Ps 70) i nr 84 (Ps 34) wszystkie pozostałe psalmy w przekładzie Jana Kochanowskiego. Psalmy 70 i 34 (nr 82 i 84 ) znajdują się w Pieśniach postnych starożytnychi z nich pewnie zostały przejęte. Ps 70 nadto był w XVI w dwukrotnie oddzielnie drukowany; por. M. Bobowski, op.cit., s. 344 . 
73. Wzywam cię, Boże, świadku mojej niewinności (Ps 4), k. $80 \mathrm{v}-81 \mathrm{v}$

74. Czasu gniewu i czasu twej zapalczywości (Ps 6), k. 81v-82

75. Zachowaj mię, o sprawco niebieskiego domu (Ps 12), k. 82$82 \mathrm{v}$

76. Dokad nie chcesz zapomnieć, dokąd śrwięta swoje (Ps 13), k. $83-83 \mathrm{v}$

77. Gtupia madrości, rozumie szalony (Ps 19), k. 83v-87v

78. Boże, czemuś mię, czemuś mię, moj wieczny (Ps 22), k. 87v89

79. Nieście chwałe, mocarze, Panu mocniejszemu (Ps 29), k. 8990

80. Będę cię wielbit, moj Panie (Ps 30), k. 90-91

82. W tobie, Panie, nadzieje mam (Ps 70; w druku oznaczono go jako Ps 31, którego łaciński incipit jest identyczny), k. 91-93 (nie jest to przekład Kochanowskiego)

83. Szczęśliwy, komu grzechy odpuszczono (Ps 32), k. 93-94v

84. Będe ja zawzidy wielbit imię Boga mego (Ps 34), k. 94v-96v (nie jest to przekład Kochanowskiego)

85. Nie obruszaj sie, że kto niewstydliwie (Ps 37), k. 96v-100v

86. Jako na puszczy prędkimi psy szczwana (Ps 42), k. 100v102

87. Niewinność, Panie, moje (Ps 43), k. 102v-103

88. Boże w miłosierdziu swoim nieprzebrany (Ps 50), k. 103$104 \mathrm{v}$

89. Bogu ufa dusza moja (Ps 62), k. 104v-106

90. Boże litościzey (Ps 64), k. 106-106v

91. Krolu na ziemi i na wielkim niebie (Ps 65), k. 107-108v

92. Obrońco uciśnionych, Boże litościzey (Ps 55), k. 109-110v

93. Zmiluj sie nade mna, Boże litościwy (Ps 56 ), k. 110v - 112

94. Ciebie my wiecznie wyznawać będziemy (Ps 75), k. 112-113

95. Pana ja wzywać będę, dokądem żywy (Ps 77), k. 113v-115

96. Owa czas, Panie, przyszedt poziadany (Ps 85), k. 115-116

97. Pohańcy, o Boże żyrey (Ps 79), k. 116v - 118

98. Kto się w opiekępoda Panu swemu (Ps 91), k. 118-119v

99. Stuszna rzecz, Panie, tobie chwate dawać (Ps 92), k. 119-121

100. Pan chce krolować, odziat sie zacnościa (Ps 93), k. 121-121v

101. Podźmy z ochota, Panu chwate dajmy (Ps 95), k. 121v-123

102. Pan kroluje, ktory wtada anjohy lotnemi (Ps 99), k. 1233$123 \mathrm{v}$

103. Ciebie, o Boże, niezmierzony (Ps 101), k. 123v-125

104. Ushysz prośbę moję, Boże litościwey (Ps 102), k. 125-127

105. Dziatki niewinne, panieńki uczciwe (Ps 113), k. 127-128

106. Jeśli domu sam Pan nie zbuduje (Ps 127), k. 128-129 
107. Wieczny Boże nie najdziesz pychy w sercu moim (Ps 131), k. 129

108. Teraz, o wierni Pańscy stużebnicy (Ps 134), k. 129v

109. Siedzac po niskich brzegach babilońskiej wody (Ps 137), k. $129 \mathrm{v}-130 \mathrm{v}$

110. Broń mię, moj Panie, od ludzi złośliwych (Ps 140), k. $130 \mathrm{v}-131 \mathrm{v}$

111. Pana wotam, Pana prosze (Ps 142), k. 131v-132v

112. Wystuchaj, wieczny Boże, prośby moje (Ps 143), k. 132v $-134 \mathrm{v}$

113. Duchy prożne śmiertelności (Ps 148), k. 134v-135v

114. Radujcie sie Bogu nawyższemu (Ps 81), k. 135v-137v

115. Chrwalcie Pana zjego śrviątobliwości (Ps 150), k. 137 - 138

Poczynają się pieśni rozmaite

116. Chwalmy Boga z wysokości, k. 138v-139v

117. Pieśń o pokusach i sidłach szatańskich: Do ciebie, Panie, swoj głos podnosze, wystuchaj, k. 139v-141

118. Pieśń o sądzie i sprawiedliwości Pańskiej: Raczcie postuchać tej sprawy, k. 141-143v

110. Czego chcesz po nas Panie za twe hojne dary, k. 144-145

120. Pieśn o morowym powietrzu: Świta, mierzcha, bieża lata, k. $145 \mathrm{v}-147 \mathrm{v}$

121. Smutne me serce w żałości omdlewa, k. $147 \mathrm{v}-148$

122. Wszechmogacy Panie mity, W twojej mocy nad cię nie jest iny (o św. Jopie), k. 148v-152v

123. O Sebastyjanie, święty męczenniku, k. 152v-153v

124. Chwała tobie, Gospodynie (o św. Stanisławie), k. 153v-156v

125. Nadobna pieśń o kozacku duchownym: O mizerna duszo $m o j a$, k. $156 \mathrm{v}-159 \mathrm{v}$

126. Nadobna pieśń o świętym Franciszku: Wimię Ojca wszechmocnego, k. 159v-162v

127. Pieśń o naświętszej Pannie: Nitida stella, casta puella, k. $162 \mathrm{v}-163$

128. Po polsku: Greiazdo jasności, Panno czystości, k. 163-164v

129. Jezu Chryste, Panie miły, Baranku barzo cierpliwy, k. 164v165

130. Martine, sancte pontifex, k. 165-165v

131. Catherine virginis laudes decantemus, k. 165v-166

132. Nicolai sollenia, sua prece familia, k. 166

133. Pieśń za Koronę Polską: Flant Domine oculi tui intendentes, k. 166-166v

134. Raczstrzec, moj Panie, k. 166v 
135. Pieśń o Pannie Maryjej Loreckiej: Krolewno najaśniejsza nieba prześrwietnego, k. 166v-168v

136. Pieśń o s. Maryjej Magdalenie: Maryja Magdalena w świecie sie kochajac, k. 168v-169v

137. Hymna nabożna o Pannie Maryjej: O gloriosa Domina, k. $169 \mathrm{v}-170$

138. O gospodze uwielbiona, k. 170-171

139. Nadobna pieśń w utrapieniu: Przydzie Panie zaginać ratunku potrzeba, k. 171-172

140. VII Psalm: Domine Deus meus, in te speravi. W tobie ja samym, Panie, człowiek smutny, k. 172-174 (przekład Jana Kochanowskiego).

\section{WIESEAW WYDRA}

\section{"Pieśni nabożne..." from the Cracow-based printing office of Antoni Wosiński (1627)}

The article analyses the unique copy of the old Polish catholic hymn book Pieśni nabożne na święta uroczyste wedlug porzadku Kościoła Ś. Katolickiego na caly rok z wielka pilnościa zebrane [Songs of piety and devotion...] published in Cracow in 1627 and found at the library at Escorial in Spain. The book, apparently the first known printed Polish catholic extensive hymn book, contained over 140 songs, in Polish and Latin, including works written by Jan Kochanowski and Mikołaj Rej. The article also describes later editions of the hymn book. This is a particularly important book in the history of Polish culture because it was repeatedly republished in different printing offices, not only Catholic, under the same or slightly changed title as late as until the nineteenth century. Numerous editions of the hymn book constitute a valuable source for the study of Polish Catholic hymns as they make it possible to follow and trace the chronology of works, their textual variations and the popularity of particular songs or hymns within a particular time frame, as well as their range of influence and regional occurrence.

Key words: Polish culture, printing in Poland, history of Polish literature, history of the book, Old-Polish religious song.

Wiesław Wydra - prof. dr hab., wykłada filologię polską na Uniwersytecie im. Adama Mickiewicza w Poznaniu. Zajmuje się historią literatury i książki w średniowieczu i w XVI wieku oraz edytorstwem tekstów staropolskich. Jest autorem ponad stu artykułów i kilku książek, m.in. Chrestomatia staropolska. Teksty do roku 1543 ( ${ }^{1} 1984,{ }^{2} 1995,{ }^{3} 2004$; wspólnie z Wojciechem Rzepką), Wtadystaw z Gielniowa. Z dziejów średniowiecznej poezji polskiej (1992), Dlaczego pod Grunwaldem śpiewano Bogurodzicę (2000), Polskie pieśni 
Íredniowieczne. Studia o tekstach (2003), Kazania świętokrzyskie. Edycja. Transliteracja, w: Kazania świętokrzyskie. Nowa edycja, nowe propozycje badawcze (2009).

e-mail: wydra@amu.edu.pl 
